\title{
First Report of Peanut Stripe Virus Infecting Groundnut (Arachis hypogaea L.) in Western Kenya
}

\author{
Anthony Simiyu Mabele*, Fredrick Wotia \\ Department of Agriculture and Land Use Management (ALUM), Masinde Muliro University of Science and Technology (MMUST), \\ Kakamega, Kenya
}

Email address:

mabeleanthony@gmail.com (A. S. Mabele)

${ }^{*}$ Corresponding author

\section{To cite this article:}

Anthony Simiyu Mabele, Fredrick Wotia. First Report of Peanut Stripe Virus Infecting Groundnut (Arachis hypogaea L.) in Western Kenya. Biochemistry and Molecular Biology. Vol. 6, No. 1, 2021, pp. 11-18. doi: 10.11648/j.bmb.20210601.13

Received: January 30, 2021; Accepted: February 14, 2021; Published: February 26, 2021

\begin{abstract}
Peanut (Arachis hypogaea) is a leguminous food crop in Kenya, whose yields are probably affected by Peanut stripe virus (PStV) belonging to the genus Potyvirus and family Potyviridae, that causes Peanut stripe disease (PSD), also referred to as groundnut stripe disease (GSD). PSD/GSD is rapidly spread through seed and mechanically transmitted in a nonpersistent manner by aphid vectors causing 30-100\% decrease in production. Different isolates of PStV induce different symptoms in groundnut ranging from striping, ring spots, vein banding and oakleaf mosaic. PStV occurrence in Kenya has neither been reported nor its resistance identified in commercial cultivars of groundnut in research stations. This informs the need for resistance breeding programmes of wild genotypes to be explored as the only practical solution. This study reports the first occurrence, distribution and molecular detection of PStV infecting groundnut in western Kenya, which is crucial in developing appropriate crop protection and plant health management strategies for this new disease. A survey of PSD was conducted in western Kenya among the four counties of Bungoma, Busia, Kisumu and Kisii during the short rains season of 2019. A total of 14 symptomatic leaf samples were selected from the collected samples and preserved until use. Total RNA was extracted from the symptomatic leaf samples using GeneJET Plant RNA Purification Mini Kit according to the manufacturers' protocol. Two-step RT-PCR detection of PStV was done using specific primers that yielded the expected $454 \mathrm{bp}$. DNA libraries were prepared and sequenced using the Sanger sequencing platform, but produced poor quality sequences after performing sequence quality check using BioEdit workbench that based on the low quality peaks of the electropherograms generated, therefore recommend for further research. To our knowledge, this is the first report of the occurrence, distribution and molecular diagnostics of PStV in Kenya. Further studies are needed to assess the molecular and biological diversity of PStV strains, the spatial distribution and the incidence of this emerging groundnut disease in Kenya.
\end{abstract}

Keywords: Occurrence, Peanut Stripe Virus, Potyvirus, Two-step RT-PCR, Western Kenya

\section{Introduction}

\subsection{Origin of Peanut Stripe Virus (PStV)}

The origin of Peanut stripe virus (PStV, genus: Potyvirus; family: Potyviridae) has been reported on groundnut (Arachis hypogaea) plants in Asia [1], United States of America (USA) [2] and South America in Ecuador (Gillaspie et al., 2000), while little is known about the occurrence and distribution of this potyvirus in Africa. PSD had previously been observed in West Africa, Senegal [3] without formal identification of the causal agent, but the virus strains identified in South Africa and Zimbabwe [4] were documented. The USA PStV virus strain originated in groundnut seed imported from China. The PStV naturally infects groundnut in China, India, Indonesia, Malaysia, Myanmar, Philippines, Thailand, USA, and Vietnam. Besides groundnut, PStV naturally infects soybean (Glycine max), cowpea (Vigna unguiculata), Indigofera amoena, Pueraria phaseoloides, Stylosanthes capitata and S. craba. PSD is seed borne and mechanically transmitted by sap as well as by the aphid vectors. Movement of infected seed has resulted in wide distribution of PStV. Based on peptide profiling of the coat protein $(\mathrm{CP})$ genes, $\mathrm{PStV}$ is serologically closely related 
to blackeye cowpea mosaic potyvirus (BICMV), Azuki bean mosaic potyvirus (AzMV) and the serogroup-B strains of bean common mosaic potyvirus (BCMV), and distantly to clover yellow vein virus (CIYVV) and soybean mosaic virus (SMV) potyviruses [5]. Initially, PStV was described as a new virus but recent serological and molecular studies have shown that it is a strain of BCMV, which also includes BICMV, AzMV and three potyvirus isolates from soybean (Glycine max). There is no genotype of cultivated groundnut that is resistant to PStV. However, several wild genotypes of Arachis spp. are highly resistant to the virus and are to be used in future breeding study programmes. The most efficient means of containing PStV is the use of virus-free seed. Although PStV has been taxonomically classified as a strain of BCMV, it differs from other strains of this virus to which it is serologically related. The BCMV species of potyviruses includes BCMV, BlCMV, AzMV and PStV. In turn, each of these viruses consists of numerous strains which have similar biological characteristics. A high level of serological cross reactivity [6] and similarity of CP peptide profiles [7] as well as sequence similarity [8] makes it difficult to unequivocally distinguish these viruses. However, differences in host range and subcellular inclusions following infection can be used to differentiate them [9].

\subsection{Transmission of Peanut Stripe Virus (PStV)}

Peanut stripe virus (PStV) is transmitted by Aphis craccivora Koch, A. gosypii Clover and Myzus persicae Sulzer, and probably by many other aphid species in a nonpersistent manner [10]. This is probably the only means by which the disease can spread from its primary source under field conditions. Aphis craccivora, A. gosypii, and Myzus persicae have been tested on their transmission efficiencies with 10 viruliferous aphids per test plant in a $1-2 \mathrm{hr}$ acquisition access period, A. craccivora transmitted the virus at $90-100 \%$ frequency, while the frequency of A. gossypii was $33 \%$ [11]. Different symptom variants of PStV could have different aphid transmission frequencies while seed transmission frequency is probably influenced by environmental conditions, virus isolates and the groundnut cultivars used [12]. The PStV transmission through groundnut seeds can be as high as $37 \%$ if the parent plants are artificially infected at an early stage [13]. However, seeds from naturally infected plants have lower seed transmission frequencies $(0-7 \%)$ and this is highly variable from plant to plant [14].

In Thailand, the transmission efficiencies of A. craccivora are $30-100 \%$ depending on the virus variants and the test conditions [15]. Many legume species grown as cover crops or pasture crops have been indexed and found to harbor PStV and its transmission vectors. Chemical applications to lessen the disease incidence have been tried but without success, hence the need for more emphasis has been given to screening germplasm. In the USA, although crop losses due to PStV have been estimated, no statistically significant data have been obtained because yields vary widely [16]. The long duration of cultivars commonly grown in the USA, the omnipresence of aphid vectors, the susceptibility of all commercially grown cultivars, the relatively high seed transmission rates and the wide host range of PStV, are all factors which may contribute to frequent epidemics of PStV. In Australia, the Australian Centre for International Agricultural Research (ACIAR) project on groundnut/peanut improvement in Indonesia, screened part of the world germplasm collections from ICRISAT and existing ACIAR projects. To date, Australia is free of PStV and importation of the virus for research purposes is unlikely to be approved because the groundnut/peanut industry is of economic importance. Antisera for PStV is held in Australia for checking the identity of suspicious symptoms either on seed grown in quarantine or on commercial crops [17], therefore PStV does not occur in Australia owing to the rigorous quarantine procedures.

PStV strains have a coat protein sequence variability of below $10 \%$ and can be defined according to geographical origin and symptom type [4]. PStV is difficult to control because it can be transmitted both through seed and aphids, and there is no natural resistance in genetically compatible germplasm. However, pathogen-mediated resistance (PMR) has been deployed successfully to provide resistance to potyvirus infection in several crops. High level resistance can be induced in plants by triggering RNA silencing, an intrinsic defense mechanism against plant viruses [18]. The rate of seed transmission depends on the cultivar infected and the period of infection [13]. Seed transmission rates of up to $50 \%$ have been observed [1], making it difficult to control the spread of PStV. Seed is imported and exported between various countries, both for processing and consumption and for incorporation of new germplasm into breeding programmes. Strict control of groundnut seed importation combined with sensitive diagnostic tests for PStV in groundnut/peanut material [19], is needed to restrict further spread of the virus globally.

\subsection{Symptoms of Peanut Stripe Virus (PStV)}

The name peanut stripe was given to the disease on the basis of visual characteristic stripes and green banding symptoms along lateral veins of young groundnut/peanut leaves [2]. Visual observation for the presence of virus symptoms during the growing season gives a good impression of the health of the crop as far as viruses are concerned in plant health management, but is a less reliable indicator of plant health. The relative merits of visual observation in some varieties and with some isolate types or strains is a complex that would need to combine visual inspection, serological and molecular diagnostics as a belt and braces approach to limiting virus incidence and severity in the field. The stripe isolate produces discontinuous stripes along the lateral veins on young quadrifoliates, older leaflets showing striping, mosaic in the form of green islands, and an oakleaf pattern. Most other PStV isolates induce initial symptoms that appear as chlorotic flecks followed by mild mottle, blotch or chlorotic ring mottle symptoms while some isolates have been reported to produce leaf necrosis [15]. 
Different isolates of serologically indistinguishable PStV strains show a high level of biological variation, inducing a wide range of distinct symptom types in groundnut such as striping, discontinuous vein banding along the lateral veins, oakleaf mosaic in groundnut characterised by dark green stripes and discontinuous banding along the lateral veins of young leaves and oakleaf pattern of older leaves, mild mottle, blotch and chlorotic rings [10]. Research by Wongkaew and Dollet looked at the symptoms caused by different strains on Chenopodium amaranticolor, groundnut, soybean and blackeye cowpea, and established that all of the viruses tested were indeed PStV [15]. However, they could be divided into distinct groups based on symptoms observed on the same cultivar as well as their reactivity to different antisera [15]. Comparisons between strains from Thailand, China, Indonesia, India, Japan, the Philippines and the USA, have showed that the Thai strains display the greatest variation of symptoms on Chenopodium amaranticolor as well as leguminous hosts including groundnut [20]. Most strains of PStV induces typical stripe or vein banding pattern described as 'blotch' PStV-B on leaves of groundnut [16]. In 1990, PStV strains causing necrosis on peanut were described from Taiwan [21] and Thailand [15]. In Florida USA, a necrotic strain of PStV was isolated from peanut and Florida beggarweed (Desmodium tortuosum) [22]. The necrotic strain from Taiwan (PStV-Ts) differs from the other PStV isolates in symptoms severity it induces in groundnut by producing necrotic lesions on leaves, with the necrosis later extending to the midribs, petioles, and sometimes to the stems [21]. This leads to stunting, severe mosaic, and systemic foliar distortion or stripe symptoms on groundnut.

In South Africa, PStV causes severe stunting of plants and great reductions in yield of cultivated groundnut and mild mottling. This findings are from investigations using a single cultivated groundnut plant showing dark green blotches that was grown in an experimental plot at the ARC-Grain Crops Institute at Brits, North-West Province, South Africa [4]. In Indonesia, the typical stripe symptoms (dark green stripes along secondary leaflet veins) has rarely been observed but was observed on one local cultivar at Muneng in 1986 while the blotch symptoms (irregular green islands within chlorotic tissue) was reported in all locations where PStV occurred [17]. The range of symptoms seem to vary with crop variety/cultivar because in all varieties, symptom expression is usually severe by six weeks after germination and reaches a plateau after two weeks later with no further symptoms development as the plants mature. In Malaysia, severe blotch symptoms produced by PStV isolates were described as groundnut mosaic [23] causing various symptoms on peanut including stripe, mild mottle and blotch sometimes surrounded by necrotic or ringspots [24]. Typical PStV infected plants are distributed randomly or are weakly aggregated within the field population. The PStV positive plants occur significantly closer together than expected if infections were random among the sampled and tested plants. Other hosts of PStV other than Peanut include soybean (Glycine max), cowpea (Vigna unguiculata), white lupine
(Lupinus albus), wild tobacco (Nicotiana benthamiana), crimson clover (Trifolium incarnatum), arrowleaf clover (T. vesiculosum), subterranean clover (T. subterraneum), sesame (Sesamum indicum), Florida beggar-weed (Desmodium tortuosum), hyacinth bean (Dolichos lablab) and patchouli (Pogostemon cablin) [25].

\subsection{PStV RNA Virus Genome}

Peanut stripe disease (PSD) isolates share most of the common properties of PStV virome and are serologically indistinguishable from the diverse geographical regions of the world, hence the ad hoc committee on PStV nomenclature proposed that they should be recognized as isolates of PStV [26]. The International Committee on Taxonomy of Viruses (ICTV) further recommended that all these isolates should be tested under identical conditions to determine their relationships [27], and the Centre de Coopération Internationale en Recherche Agronomique pour le Développement (CIRAD) at Montpellier, France, accepted the responsibility in early 1989 when the experiment started for precise identification and multi locational testing of groundnut germplasm for PStV resistance [16]. Since potyviruses represent the largest group of known plant RNA viruses and includes many agriculturally important viruses, $\mathrm{PStV}$ is a member of the Potyvirus genus of plant viruses in the family Potyviridae with a single-stranded positive-sense RNA genome of approximately $10 \mathrm{~Kb}$ [2]. The PStV contains a single open reading frame (ORF) encoding a polyprotein which is post-translationally cleaved into atleast eight individual proteins required for virus replication and movement [28]. Characterisation of potyviruses related to bean common mosaic virus (BCMV) using serology and peptide profiling studies, have led to PStV being taxonomically classified as a groundnut/peanut (Arachis hypogaea L.) infecting strain of BCMV [6;7]. Sequence comparison studies by [8] and [29] have shown that while PStV strains can be classified as members of the BCMV group, they are clearly distinct from the other viruses in this group.

The PStV consists of filamentous flexuous rods, approximately $752 \mathrm{~nm}$ long and $12 \mathrm{~nm}$ in diameter with a sedimentation coefficient of $150 \mathrm{~S}$ and buoyant density in cesium chloride of $1.31 \mathrm{gcm}^{-3}$ [30]. Each particle consists of a single protein species of 33500 daltons with a major polypeptide of 35600 daltons and two minor polypeptides of 33400 and 27000 daltons. The two minor polypeptides may have been derived as a result of proteolysis of the major polypeptide. The genome is a single stranded (ss) positivesense RNA molecule of about 9500 nucleotides. The molecular weight of denatured RNA is $3.49 \times 10^{6}$ daltons [31]. The complete genome of PStV is 10,056 nucleotides (nt) in length, excluding the poly (A) tail at the $3^{\prime}$ end. The $5^{\prime}$ and $3^{\prime}$ untranslated regions (UTR) consists of $134 \mathrm{nt}$ and 254 nt respectively [32]. PStV genome has a single open reading frame (ORF, nt 134-9802) encoding a polyprotein of 3222 amino acids with an estimated molecular mass of $365.89 \mathrm{kDa}$. Phylogenetic analysis of PStV and nine closely 
related potyviruses based on the whole genomic nucleotide sequences with the optimal Tamura - Nei (TN93) model for nucleotide substitution indicated that PStV and BCMV lineage may share a common ancestor, with separation of PStV and BCMV occurring before speciation of the viruses in the BCMV lineage. According to Flasinski et al, the complete genomic sequence of PStV will assist in the development of molecular diagnostic tests and effective disease management strategies [32]. Comparison of the nucleotide and amino acid sequences of genes between PStVTs and PStV-B showed that both shared over 90\% identities, excluding the P1 gene. The DAG motif involved in aphid transmission, the conserved active site GDD motif of the core replicase and the KITC and PTK motifs found in the Nterminal of the $\mathrm{CP}$, NIb and Hc-Pro genes of PStV-Ts, BCMV-Y, BCMV-R, PStV-B and BlCMV-TW, are helpful in the comparison of multiple alignments of nucleotide and amino acid sequences among the different strains of BCMV.

\subsection{PCR Base Pair (bp) Products Size of Peanut Stripe Virus (PStV)}

Although reverse transcription-polymerase chain reaction (RT-PCR) has been shown to detect PStV in peanut seed [33], it has not been tested on a significant scale in Ecuador [34] and by extension Africa. Research by Gillaspie et al applied a high-capacity sensitive PStV diagnostics method using immunocapture-reverse transcription-polymerase chain reaction (IC-RT-PCR) [34; 5]. The forward PStV primer sequence $\left(5^{\prime}\right.$ to $\left.3^{\prime}\right)$ was GGCGAGTATGAAATAGAT and the reverse PStV primer was GGTGGTAAAACCACACTG with an expected product size of $611 \mathrm{bp}$ based on a previously reported nucleic acid sequence [35]. The CP gene of the Thailand strains T1, T3, T5, T6 and T7 yielded $129 \mathrm{bp}$ of the NIb gene, 855 bp of the CP gene and $203 \mathrm{bp}$ of the 30NCR for T1 strain; $858 \mathrm{bp}$ length of the coat protein coding region for T3 and T7 strains; 320 bp of NIb sequence and $858 \mathrm{bp} \mathrm{CP}$ coding region for T5 strain; 30NCR, $858 \mathrm{bp}$ of the $\mathrm{CP}$ gene and $122 \mathrm{bp}$ of the NIb gene of the entire PCR product length for strain T6 using the primers PST1 (5'GCATGCCCTCGCCATTGCAA-3', Upstream PST4 (5'TACATAGCAGAATCAGCACT-3', PST6 Oligo dT/adapter (5'-T17 AGCTACAGCTGAGCTCAG-3'), a primer that anneals to PStV at position $8796-8817$ in the $\mathrm{NIb}$ region (\#3361, 5'-ATGGAGGAGCTCCGTACATAGC-3') and a 3' adapter primer (\#2769, 5'-GAGCTCAGCTGTAGCT-3') [36].

Research by Dietzgen et al used RT-PCR assays based on identical cycling parameters, and identified PStV through production of the expected specific DNA fragments of 234 bp from a purified preparation of PStV-Ib using PStV specific primer sequences from $5^{\prime} \rightarrow 3^{\prime}$ of antisense PST1 5' GCATGCCCTCGCCATTGCAA 3' and Sense PST 2 5' GCACACACTTCTTGGCATGG 3' [37; 4]. Research by Choi et al indicated that the PStV CP was presumed to be 287 residues long and was the same length as the blotch strains [11]. Research findings by Gillaspie et al in Ecuador yielded positive PStV IC-RT-PCR products of 611 bp products from the peanut samples and in the PStV composite seed sample verified by ELISA [34].

\subsection{Global Distribution of Peanut Stripe Virus (PStV)}

Potyviruses spread primarily by seed transmission and secondarily by aphid vectors transmitting potyviruses in a non-persistent manner [38]. The increase in exchange of peanut germplasm has increased PStV spread in China, USA, Philippines, Thailand, Indonesia, India, Japan, Malaysia, Myanmar, Vietnam, Korea [2; 23], and many other countries including some African countries in West Africa, Senegal [3], South Africa and Zimbabwe [4] and now in East Africa, Kenya. Research has suggested that Thailand is the epicenter of PStV origin [15], considering that it was first reported in this country as early as 1972 with a wide range of biological strains of PStV identified [15]. PStV has been found in seed lots imported into a number of countries from the People's Republic of China (figure 1), and this virus has the potential to spread very rapidly hence it may be more widely distributed than is now known in Africa, apart from South Africa, Zimbabwe, Senegal, Ivory Coast (Cote d'Ivoire) and now Kenya.

In South Africa, PStV was identified in a groundnut plant grown from seed imported into South Africa from USA in 1995 [4]. Host range, serology and electron microscopy studies indicated that the infective agent was an isolate of PStV that was confirmed by sequencing the CP gene and a portion of the 3' untranslated region of the virus, and comparing it with known strains of PStV. The local strain (PStV-95/399) was related to but distinct from strains of PStV reported from the USA. PStV-95/399 and the USA strains probably had a common ancestor, but the 95/399 sequence appeared to have diverged to a greater extent from this ancestral sequence [4]. Phylogenetic analysis indicated that 951399 strain probably originated in the USA [2]. First reports of PStV reported in South Africa [4], West Africa [3], and now in East Africa, calls for the need to unravel this new disease phenomenon spreading through seed and insect vectors.

In West Africa, PStV is assumed to have originated from Asia, possibly from the People's Republic of China through seed transmission [3]. Groundnut seeds in Senegal from China in 1989 produced plants which showed symptoms resembling those caused by some PStV isolates. Electron microscopy studies, mechanical transmission tests, and examination of serological properties conducted at LPRC confirmed the presence of PStV. The virus is easily transmitted mechanically and induces a range of symptoms on groundnut including green blotches, mosaic, stripe, and mottle depending on the variety of the groundnut cultivar and the duration of symptom expression, and induced yellow spots symptoms on Chenopodium amaranticolor [3]. Negative staining (leaf dip) revealed long flexuous particles and in ultrathin sections, pinwheel inclusions characteristic of potyvirus were observed indicating a possibility that more than one strain of PStV was present in these seeds [3]. 


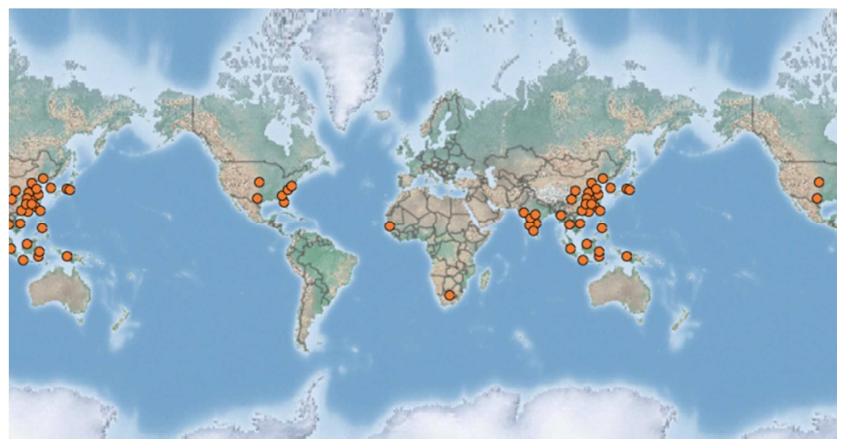

Figure 1. Map showing global distribution of PStV. The orange dots represent PStV global distribution [39].

\section{Materials and Methods}

\subsection{Field Survey}

Symptomatic groundnut leaves were collected during the extensive field survey conducted in groundnut farms of four counties in Bungoma, Busia, Kisumu and Kisii during the short rains season of 2019. A total of 14 samples were selected from the collected leaf samples and placed into falcon tubes containing RNAlater solution for storage until use. The survey was conducted by walking through groundnut fields and visually inspecting groundnut crop for symptomatic leaves. Depending on the farm size, quadrats of $10 \mathrm{~m}^{2}$ were estimated with disease incidence and severity scored on the disease diagnostic score sheet for each quadrat through random sampling. The Geographical Positioning Remote System (entrex venture HC GARMIN ${ }^{\mathrm{TM}}$ ) was used to record the latitude, longitude and altitude of the sampled farms.

\subsection{Molecular Diagnostics of PStV}

The fourteen isolates of PStV from 4 different counties in western Kenya were analysed by two-step RT-PCR at the Unit Interactions Plantes Microorganismes Environnement (UMR IPME) in the Institut de Recherche pour le Développement (IRD), Montpellier, France. Total RNA was extracted using the GeneJET Plant Purification Mini Kit (Thermo Scientific) according to the manufacturer's protocol with modifications on the PCR cycles during the repeat experiment. The leaf tissue was homogenized in liquid nitrogen and in lysis buffer provided in the kit. The PStV degenerate primer pair of CP9502 5'GCGGATCCTTTTTTTTTTTTTTTTT-3' specific for 3' end Potyvirus genome and CPUP 5'TGAGGATCCTGGTGYATHGARAAYGG-3' where $Y=C / T$, $\mathrm{H}=\mathrm{A} / \mathrm{T} / \mathrm{C}, \mathrm{R}=\mathrm{A} / \mathrm{G}$ specific for $\mathrm{CP}$ region of the $\mathrm{PStV}$ Potyvirus [25] were used as templates for RT-PCR at $10 \mu \mathrm{M}$, in transcription and amplification of the targeted $\mathrm{CP}$ gene. The sense primers were also utilized in the two-step RT-PCR to transcribe and amplify genome fragments with the $\mathrm{CP}$ gene of PStV. Amplification of the two-step RT-PCR products was done using both sense and antisense PStV specific primers under the following conditions; Denaturation at $94^{\circ} \mathrm{C}$ for 3 minutes followed by 30 cycles at $94^{\circ} \mathrm{C}$ for 1 minute, Hybridization at $60^{\circ} \mathrm{C}$ for 1 minute, Elongation at $72^{\circ} \mathrm{C}$ for 1 minute and final extension at $72^{\circ} \mathrm{C}$ for 10 minutes. The resultant reaction mixture was stored at $4{ }^{\circ} \mathrm{C}$. The PCR products were loaded and visualized in $1 \%$ Agarose gel electrophoresis stained with Ethidium bromide $(\mathrm{EtBr})$ in a X0.5 Tris Acetate EDTA buffer at $100 \mathrm{~V}$ for 30 minutes to determine the DNA size by visualizing under UV light. The findings of this study were compared with earlier studies by [3] who compared twenty four isolates of PStV from 8 different countries under controlled conditions, at the Centre de Coopération Internationale en Recherche Agronomique pour le Développement (CIRAD), Montpellier, France. The 24 isolates had their origins from Burma, India, Indonesia, Philippines, China, Thailand and USA. Four of the isolates were collected from Thailand in 1972 but maintained in Japan and sent to France for analysis $[15 ; 3]$.

\section{Results}

\subsection{Symptom Distribution of PStV}

The PStV symptoms observed in the field varied depending on the groundnut cultivar (figure 2).

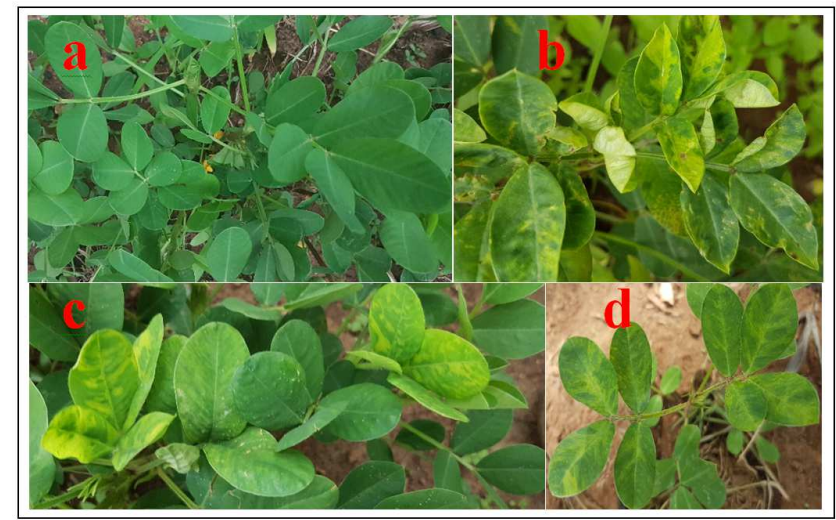

Figure 2. PStV symptoms observed in the survey field.

a: Healthy groundnut crop b: stripe, mild mottle and discontinuous vein banding along the lateral veins symptoms c: Oakleaf mosaic characterised by dark green stripes and discontinuous banding along the lateral veins of young leaves and oakleaf pattern of older leaves symptoms d: blotch surrounded by necrotic or chlorotic ring spots and mild mottle symptoms.

\subsection{RT-PCR Detection of PStV}

Ten samples from the selected fourteen during the extensive field survey in groundnut farms were tested by RTPCR to detect PStV using the purchased primers by [25]. Five samples (2, 3, 7, 9 and 12) tested positive for PStV with 454 bp product size (figure 3). Since the PCR gel was not of good quality, the PCR protocol was repeated for the positive samples (2, 3, 7, 9 and 12) but with modifications by increasing the concentration amount of cDNA and by increasing the PCR cycles from 30 to 35 cycles at $94^{\circ} \mathrm{C}$ for 1 minute that yielded a better PCR gel (figure 4).

The expected band size was $454 \mathrm{bp}$ from the specific primers used. Lane M-1kb Ladder, Isolates in lanes 1- 10 
western Kenya, 11-Negative control, 12-Positive control.

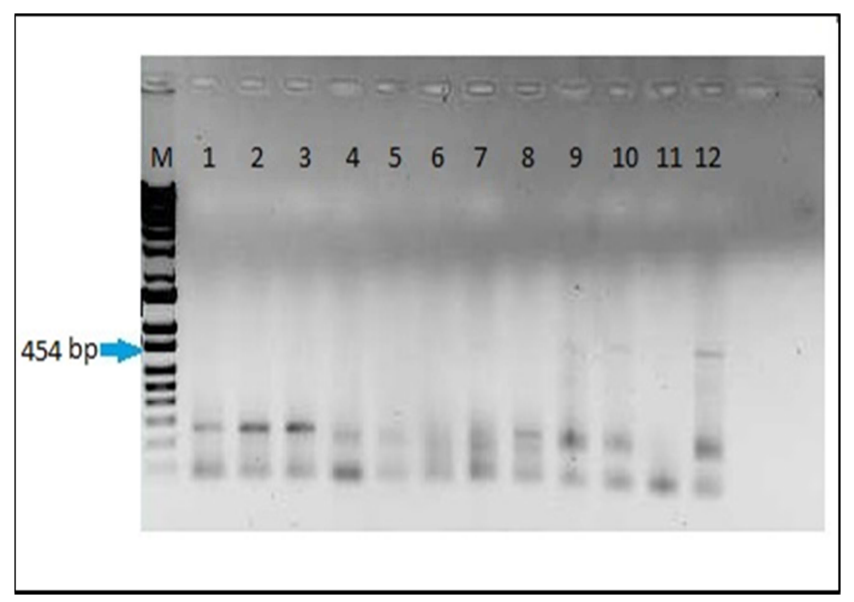

Figure 3. PCR gel for PStV.

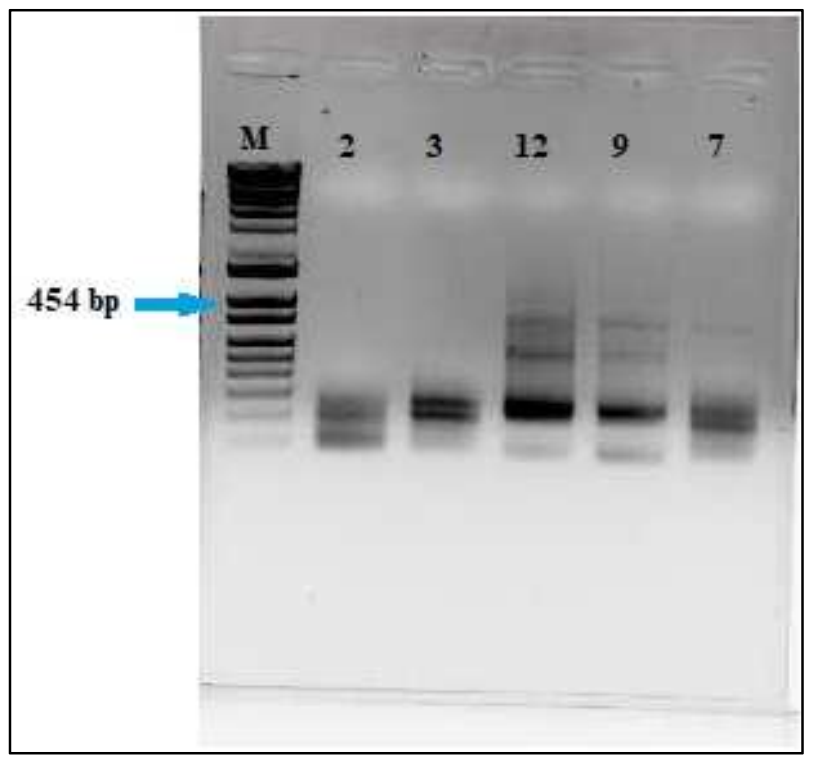

Figure 4. Peanut Stripe Virus (PStV) PCR gel for PStV.

The expected band size was $454 \mathrm{bp}$. Lane M-1kb ladder. Isolates for lanes 2, 3, 12, 9 and 7 were from western Kenya.

\section{Discussion}

\subsection{Field Survey Symptoms Diversity of PStV}

Groundnut/peanut farms were moderately to severely infected by PStV symptoms with incidences varying significantly. The high prevalence of PStV symptoms in western Kenya could be attributed to its dual infection by both seed and the aphid vector build-up, and contact hours for inoculum transmission that increases transmission efficiency and spread to nearby plants. PStV symptoms have not been previously reported to occur in Kenya but this study recorded its first occurrence in the surveyed counties of western Kenya. The PStV symptom types of stripe, mild mottling and blotching sometimes surrounded by chlorotic or necrotic ringspots could possibly indicate that some PStV variant strains occur in western Kenya in mixed infections, hence causing the varied symptom types observed that needs further research.

\subsection{Molecular Diagnostics}

The molecular bioassays used detected presence of PStV occurrence in western Kenya by efficiently amplifying the coat protein $(\mathrm{CP})$ gene, and produced the expected RT-PCR gel product of 454 bp with some unexpected 250 and 300 base pairs indicating presence of variant strains of PStV. However, the RT-PCR amplification of PStV CP fragment by [25] primers used on Patchouli plants with $454 \mathrm{bp}$ and $800 \mathrm{bp}$ using $1000 \mathrm{bp}$ marker, was not efficient even though the expected product of the diagnostic primers for PStV amplified very well. It is likely that the inefficient annealing of the primers to its predicted binding site, would not become apparent until attempts are made to amplify a larger product such as the full-length $\mathrm{CP}$ sequence, and the use of other related PStV primers such as the universal primers for PStV Upstream T7 5'-TAATACGACTCACTATAGGG-3' and Downstream SP6 5'-ATTTAGGTGACACTATAG-3'among others, on symptomatic groundnut samples for comparison and eliminate erroneous PCR products. The South African PStV diagnostic primers used by Flasinski et al of PST1- 5' GCATGCCCTCGCCATTGCAA $\quad 3$ ', $\quad$ PST2- 5' GCACACACTTCTTGGCATGG 3', PST4- 5' TACATAGCAGAATCAGCACT 3', PST5- 5' GCCTTTCAGTATTCTCGCTG 3', and PST6- 5' CAATGAGAGACAAGGATG 3', gave a $234 \mathrm{bp}$ and $370 \mathrm{bp}$ RT-PCR product and 1194 bp full-length PCR fragment [31].

Sequencing of the PCR product derived from preferential amplification of the 3'-end of the PStV CP gene confirmed its identity as PStV. Phylogenetic analysis clearly supports PStV distinction as a species of the genus Potyvirus that is most closely related to Bean common mosaic virus (BCMV) and Blackeye cowpea mosaic virus (BICMV) [32]. However, the Sanger sequences analysed from this study produced poor quality sequences of the $\mathrm{CP}$ gene after performing sequence quality check using BioEdit workbench that revealed the low quality peaks of the electropherograms generated. This might have resulted from mispriming, lower quality gel due to some degree of serological/molecular cross reactivity with some other potyviruses, lower sample size of the symptomatic leaves and therefore further diagnostic assays and use of Next Generation Sequencing (NGS) or HiFi Reads for highly accurate long-read sequencing by Circular Consensus Sequencing (CCS) technologies are recommended for use to infer this conclusion. The complete genome of PStV is 10 , 056 nucleotides (nt) in length from the Laixi isolate of Peanut stripe virus (PStV-Laixi) from China while excluding the poly (A) tail at the 3' end [32]. The 5' and 3' untranslated regions (UTR) consist of $134 \mathrm{nt}$ and $254 \mathrm{nt}$, respectively [32].

\section{Conclusion}

In conclusion, Peanut stripe virus (PStV) occurs in Kenya, but incidence tends to be varied depending on the groundnut 
cultivar. The PStV has been found in seed lots imported into a number of countries from China, and this virus has the potential to spread very rapidly hence virus diagnosis is an important component of field surveys. Annual PStV surveys are necessary to determine the incidence, severity and distribution of the disease because it may be more widely distributed than is now known. The extensive field surveys will also assist in the understanding of the etiology, pathotyping and epidemiology of PSD to help in management through cultural practices, cropping systems, planting dates and determining what other factors to incorporate when breeding for PStV resistant varieties. The occurrence of PStV in Kenya has not been reported and we believe this is the first report of PSD/GSD occurrence. The findings of this study are a clear indication that with increase in exchange of germplasm among countries, it is imperative for plant breeders and plant virologists to work in close association to manage/control PSD. Special care should be taken when introducing exotic germplasm into Kenya and other developing countries where PStV is currently not known to occur to avoid the introduction of the virus.

\section{Recommendations}

This study recommends that;

1) Although extensive studies have been devoted to the characterization of plant viruses to help minimize virusinduced losses of tropical legumes and other crops, still thorough knowledge on the epidemiology, properties of potyviruses like PStV, bioecology of the principal aphid vectors, cultivated and uncultivated crop hosts of both viruses and vectors is required to better understand the molecular plant-virus interactions for the development of novel antiviral strategies.

2) An adequate sample size in relation to established procedures should be used, and considerations should be given to making surveys that utilize deep sequencing techniques that are reliable with sensitive diagnostic assays as an annual exercise, in order to keep pace with new pathogenic challenges in production of the high value groundnut crop in Kenya.

3) Groundnut exporting countries should ensure that seed lots in planting stock are free from seed-transmitted groundnut viruses, and vigilance should be exercised to prevent introduction of exotic diseases through international collaboration and stringent quarantine procedures.

\section{Declaration of Interest}

The authors have not declared any conflict of interest.

\section{Acknowledgements}

This study was funded by the Biotechnology and Biological Sciences Research Council (BBSRC), Funding Body Reference-BB/R005397/1 under the Project
"CONNECTED - Community Network for African VectorBorne Plant Viruses" by the Global Challenges Research Fund (GCRF) Research Grant, facilitated by the department of Life Sciences, University of Bristol, United Kingdom (UK).

The Molecular diagnostic assays were funded by Unit Interactions Plantes Microorganismes Environnement (UMR IPME), Institut de Recherche pour le Développement (IRD), Montpellier, France.

The funding bodies together with collaborators had no role in the study design, data collection and interpretation or the decision to submit the work for publication.

\section{References}

[1] Xu, Z., Chen, K., Zhang, Z. \& Chen, J. (1991). Seed transmission of peanut stripe virus in peanut. Plant Dis. 75: 723-726.

[2] Demski, J. W., Reddy, D. V. R., Sowell, G. \& Bays, D. (1984). Peanut stripe virus: A new seed-borne potyvirus from China infecting groundnut (Arachis hypogaea). Ann. Appl. Biol. 105: 495-501.

[3] Dollet, M. \& Dubern, J. (1991). Peanut Stripe Virus: Potential Danger for Groundnut in western Africa. In: ICRISAT (International Crops Research Institute for the Semi-Arid Tropics). 1991. Groundnut virus diseases in Africa. Patancheru, A. P. 502 324, India: ICRISAT. Page 26.

[4] Higgins, C. M., Cook, G., Pietersen, G. \& Dietzgen, R. G. (1999). Molecular characterisation of a strain of peanut stripe potyvirus from groundnut germplasm imported into South Africa. Afr. Plant Prot. 5 (1): 5-12.

[5] Nolasco, G., De Blas, C., Torres, V. \& Ponz, F. (1993). A method combining immunocapture and PCR amplification in a microtiter plate for the detection of plant viruses and subviral pathogens. J. Virol. Methods. 45: 201-218.

[6] McKern, N. M., Shukla, D. D., Barnett, O. W., Vetten, H. J., Dijkstra, J., Whittaker, L. A. and Ward, C. W. (1992). Coat protein properties suggest that azuki bean mosaic virus, blackeye cowpea mosaic virus, peanut stripe virus and three strains from soybean are all strains of the same potyvirus. Intervirology. 33: 121-134.

[7] Vetten, H. J., Lesemann, D. E. \& Maiss, E. (1992) Serotype A and B strains of BCMV are two distinct potyviruses. In: Barnett, O. W. (ed), Potyvirus taxonomy. Springer, Wien New York. 5: 415-431 (Arch Virol [Suppl] 5).

[8] Berger, P. H., Wyatt, S. D., Shiel, P. J., Silbernagel, M. J., Druffell, C. \& Mink, G. I. (1997). Phylogenetic analysis of the Potyviridae with emphasis on legume-infecting potyviruses. Arch Virol. 142: 1979-1999.

[9] Edwardson, J. R. \& Christie, R. G. (1991). A monograph on the potyvirus group. Agronomy Department, Florida Agricultural Experiment Station, University of Florida.

[10] Fukumoto, F., Thongmeearkom, P., Iwaki, M., Choopanya, D., Sarindu, N., Deeman, N. and Tsuchizaki, T. (1986). Peanut chlorotic ring mottle virus occurring on peanut in Thailand. Technical Bulletin of the Tropical Agricultural Research Center, Japan. 21: 150-157. 
[11] Choi, H. S., Kim, J. S., Cheon, J. U., Choi, J. K., Pappu, S. S. \& Pappu, H. R. (2001). First Report of Peanut stripe virus (Family Potyviridae) in South Korea. Plant Dis. 85: 679.

[12] Xu, Z. Y., Yu, Z. L., Liu, J. L. \& Barnett, O. W. (1983). A virus causing peanut mild mottle in Hubei province, China. Plant Dis. 67: 1029-1032.

[13] Demski, J. W. and Lovell, G. R. (1985). Peanut stripe virus and the distribution of peanut seed. Plant Dis. 69: 734-738.

[14] Demski, J. W. and Reddy, D. V. R. (1988). Peanut stripe virus disease in the USA. Pages 10-11 in Coordination of research on peanut stripe virus: Summary proceedings of the First Meeting to Coordinate Research on Peanut Stripe Virus Disease of Groundnut, 9-12 Jun 1987, Malang, Indonesia. Patancheru, A. R 502 324, India. International Crops Research Institute for the Semi-Arid Tropics.

[15] Wongkaew, S. \& Dollet, M. (1990). Comparison of peanut stripe virus isolates using symptomatology on particular hosts and serology. Oleagineux. 45: 267-278.

[16] Demski, J. W., Reddy, D. V. R., Wongkaew, S., Xu, Z. Y., Kuhn, C. W., Cassidy, B. G., Shukla, D. D., Saleh, N., Middleton, K. J., Sreenivasulu, P., Prasada Rao, R. D. V. J., Senboku, T., Dollet, M., and McDonald, D. (1993). Peanut stripe virus. Inf. Bull. No. 38, Peanut Collaborative Res. Support Prog. (Peanut CRSP) University of Georgia, Griffin 30223 and International Crops Research Institute for the Semi-Arid Tropics (ICRISAT) Patancheru, Andhra Pradesh 502324, India.

[17] Roechan, M., Iwaki, M., Nasir, S., Tantera, D. M. \& Hibino, H. (1978). Virus diseases of legume plants in Indonesia: Peanut Mottle Virus Contribution of Central Research Institute for Agriculture, Bogor, No 46: pp 1-11.

[18] Waterhouse, P. M., Wang, M. B. \& Lough, T. (2001). Gene silencing as an adaptive defence against viruses. Nature. 411: 834-842.

[19] Dietzgen, R. G., Xu, Z. \& Teycheney, P. V. (1994). Digoxigenin-Iabeled cRNA probes for the detection of two potyviruses infecting peanut (Arachis hypogaea). Plant Dis. 78: 708-711.

[20] Wongkaew S. (1986). Peanut stripe and other viruses in Thailand. In: Proceedings of Peanut CRSP Workshop. pp 8690. Khon Kaen, Thailand.

[21] Chang, C. A., Purcifull, D. E. \& Zettler, F. W. (1990). Comparison of two strains of peanut stripe virus in Taiwan. Plant Dis. 74: 593-596.

[22] Sreenivasulu, P., Demski, J. W., Kuhn, C. W. \& Christie, R. G. (1992). Characterization of a necrosis strain of peanut stripe virus infecting beggar-weed and groundnut in Georgia. Int. Arachis Newsl. 11: 21-23.

[23] Xu, Z. Y. \& Chen, K. R. (2008). Viruses and Viral Diseases of Oil Crops (In Chinese). Beijing, China, Chemical Industry Press.

[24] Prasada Rao, R. D. V. J., Reddy, A. S., Chakrabarty, S. K., Reddy, D. V. R., Rao, V. R., and Moss, J. P. (1991). Identification of peanut stripe virus resistance in wild Arachis germplasm. Peanut Science. 18: 1-2.
[25] Singh, M. K., Chandel, V., Hallan, V., Ram, R. \& Zaidi, A. A. (2008). Occurrence of Peanut stripe virus on Patchouli and raising of virus-free Patchouli plants by meristem tip culture. J. Plant Dis Prot. 116 (1): 2-6.

[26] Demski, J. W. \& Warwick, D. (1986). Testing peanut seeds for peanut stripe virus. Peanut Science. 13: 38-40.

[27] ICRISAT. (1988). Coordination of research on peanut stripe virus: Summary proceedings of the First Meeting to Coordinate Research on Peanut Stripe Virus Disease of Groundnut. 9-12 June 1987. Malang, Indonesia, Patancheru, A. P. 502 324, India: ICRISAT.

[28] Culver, J. N., Sherwood, J. L. \& Melouk, H. A. (1987). Resistance to peanut stripe virus in Arachis germplasm. Plant Dis. 71: 1080-1082.

[29] Higgins, C. M., Cassidy, B. G., Teycheney, P. Y., Wongkaew, S. \& Dietzgen, R. G. (1998). Sequences of the coat protein gene of five peanut stripe virus (PStV) strains from Thailand and their evolutionary relationship with other bean common mosaic virus sequences. Arch Virol. 143: 1655-1667.

[30] Saleh, N., Horn, N. M., Reddy, D. V. R. \& Middleton, K. J. (1989). Peanut stripe virus in Indonesia. Neth. J. Plant Pathol. 95: 123-127.

[31] Flasinski, S., Gunasinghe, U. B., Gonzales, R. A. \& Cassidy, B. G. (1996). The cDNA sequence and infectious transcripts of peanut stripe virus. Gene. 171: 299-300.

[32] Xu, M., Gao, F., Yang, J., Wu, J., Xie, L. and Chi, Y. (2014). Complete Genome Sequence of Peanut stripe virus Isolated in China. J Phytopathol. doi: 10.1111/jph.12248.

[33] Sherwood, J. L., Pennington, R. E., Cassidy, B. G. \& Nelson, R. S. (1992). Detection of Peanut stripe virus in peanut seed using the RNase inhibitor (Promega Corp., Madison, WI) polymerase chain reaction. (Abstr.) Proc. Am. Peanut Res. Edu. Soc. 24: 39.

[34] Gillaspie, A. G., Jr., Pittman, R. N., Pinnow, D. L. \& Cassidy, B. G. (2000). Sensitive method for testing peanut seed lots for Peanut stripe and Peanut mottle viruses by immunocapturereverse transcription-polymerase chain reaction. Plant Dis. 84: $559-561$.

[35] Cassidy, B., Sherwood, J. L. \& Nelson, R. S. (1993). Cloning of the capsid protein gene from a blotch isolate of peanut stripe virus. Arch. Virol. 128: 287-297.

[36] Gunasinghe, U. B., Flasinski, S., Nelson, R. S. \& Cassidy, B. G. (1994). Nucleotide sequence and genome organisation of peanut stripe potyvirus. J Gen Virol. 75: 2519-2525.

[37] Dietzgen, R. G., Callaghan, B., Higgins, C. M., Birch, R. G., Chen, K., and $\mathrm{Xu}, \mathrm{Z}$. (2001). Differentiation of peanut seedborne potyviruses and cucumoviruses by RT-PCR. Plant Dis. 85: 989-992.

[38] Mishra, A., Gohel, V. R., Valand, G. B., Patel, J. G. \& Shukla, D. D. (1993). Peanut stripe virus disease of groundnut: A review. Int J Pest Manag. 39: 210-215.

[39] Anon, (1996). Viruses of plants. Descriptions and lists from the VIDE database. [ed. by Brunt A A, Crabtree K, Dallwitz M J, Gibbs A J, Watson L]. Wallingford, UK. CABI International. $1484 \mathrm{pp}$. 